\title{
Use of agro-industrial by-products for fattening lambs: pasta factory residues. Influence on meat production and meat quality
}

\section{Trabalza Marinueci ${ }^{1}$, V. Ippedico ${ }^{2}$, G. Martino ${ }^{3}$, P. Polidori ${ }^{1}$, Anna R. Loschi ${ }^{4}$ and M. Severini ${ }^{4}$}

\author{
'Faculty of Veterinary Medicine, State University of Camerino \\ Via Circonvallazione 93, 62024 Matelica (MC). Italy \\ ${ }^{2}$ Institute of Animal Production, State University of Perugia \\ Via S. Costanzo. 06100 Perugia, Haly \\ ${ }^{3}$ Institute of Animal Husbandry, State University of Teramo \\ Località Piano D'Accio, 64020 Nepezzano (TE), Italy \\ ${ }^{4}$ Institute of Food Hygiene and Technology, State University of Perugia \\ Via S. Costanzo, 06100 Perugia. Italy
}

(Received 20 January 1998; accepted 24 June 1998)

\section{ABSTRACT}

Thirty-four male crossbred lambs were divided at weaning ( 40 days) into two groups, avcraging the same liveweight $(13.5 \pm 0.25 \mathrm{~kg})$. During the experimental period, all of the animals received one of two different types of concentrate over a period of 70 days. The control concentrate contained barley as the main source of starch, the experimental feed was prepared with pasta factory residues (PFR) partially substituting the barley. Body liveweight and average daily gain during the first five weeks of the trial were significantly higher $(P<0.01)$ in the PFR group; during the second part of the experiment no significant differences werc found between the two groups. The feed conversion ratio was not affected by the diet. Slaughtering data ( $30 \mathrm{~kg}$ final body weight) showed no signilicant differences between groups. Chemical and fatty acid compositions of longissimus thoracis lumborum muscle were not signilicantly different between control and PFR lambs. No differences in sensory traits or shear force values for semimembranosus muscle were detected when comparing all carcasses in each group. Considering the overall results and the availability of PFR, this by-product could be profitably included in diets for small ruminant. 


\section{INTRODUCTION}

Use of agro-industrial by-products in small ruminant nutrition to reduce breeding costs has met with great interest in recent years. In a trial conducted by Vicenti et al. (1993) the use of almond hulls and safflower cake in fattening lambs was investigated : when fed a diet containing $10 \%$ mechanically extracted safflower cake lambs showed a higher dressing percentage at slaughtering compared to the control group; $15 \%$ almond hulls added to the diet gave as a result higher pelt and head percentages. Centoducati et al. (1994) conducted an experiment aimed at assessing the effects of diets containing different amounts of trub, a beer brewing by-product, on lamb carcass and meat quality; higher liveweight gains were observed for the control group, while a lighter colour of meat was the only effect of trub on product quality. Recently, Ragni et al. (1997) carried out a scrics of experiments on the effects of grape skins in lamb-meat nutrition: performance, carcass and meat characteristics of lambs fed with mixed diets made up of grape skins were satisfactory and competitive when compared with the control group.

Among other agro-industrial by-products, pasta factory residues have aroused little interest in the past, even though many farmers in southern Italy are interested in the possibility of using them as an animal feed. Including pasta factory residues in mixed feeds could reduce livestock feeding costs. In the present work, this byproduct was added to the diet of a group of fattening lambs. The experimental treatment was compared to a control diet in which barley was the main cereal in the ration.

\section{MATERIAL AND METHODS}

\section{Animals and feed}

Thirty-four male crossbred lambs (Bergamasca x Comisana/Leccese) reared on the same farm were used in this trial. Lambs were divided at weaning ( 40 days) into two groups of 17 animals, averaging the same liveweight $(13.5 \pm 0.25 \mathrm{~kg}$ ). Before weaning all lambs were fed a commercial concentrate with the following composition ( $\%$ as fed): moisture 13.0 , crude protein 17.8 , crude fibre 6.0 , ether extract 4.0, and ash 7.2. During the 70-day experimental period, the two groups of animals received twice daily $(07.00$ and $18.00 \mathrm{~h})$ two different types of concentrate, formulated to be isonitrogenous and isoenergetic (Table 1): a control (C), with barley as the main source of starch, and an experimental feed (PFR) in which pasta factory residues, based on wheat meal, were used to partially substitute the barley (Table 1). The composition of PFR was as follows ( $\%$ as fed): moisture 11.7 , crude protein 11.4 , ether extract 0.4 , crude fibre 0.2 , and ash 0.7 . Lambs 
TABLE 1

Ingredients and chemical composition of concentrates, $\%$ as fed'

Concentrates

control pasta factory residues

$\begin{array}{lcc}\text { Ingredients } & & \\ \text { barley meal } & 54.50 & 13.00 \\ \text { pasta factory residues } & - & 36.50 \\ \text { soyabean mcal } & 30.00 & 31.00 \\ \text { wheat middlings } & 7.50 & 7.50 \\ \text { wheat straw } & - & 4.00 \\ \text { molasses } & 2.00 & 2.00 \\ \text { soyabean oil } & 1.00 & 1.00 \\ \text { dicalcium phosphatc } & 2.50 & 2.50 \\ \text { calcium carbonate } & 2.00 & 2.00 \\ \text { vitamin-trace elements supplement } & 0.50 & 0.50\end{array}$

Chemical composition, \%

$\begin{array}{lrr}\text { dry matter } & 90.25 \pm 0.82 & 90.80 \pm 1.03 \\ \text { crude protein } & 20.22 \pm 0.42 & 20.95 \pm 0.28 \\ \text { crude fat } & 2.92 \pm 0.11 & 2.48 \pm 0.39 \\ \text { ash } & 7.14 \pm 0.30 & 7.18 \pm 0.05 \\ \text { NDF } & 14.88 \pm 0.32 & 11.67 \pm 0.02 \\ \text { ADI: } & 6.62 \pm 1.05 & 6.14+1.51 \\ \text { ADL } & 1.35 \pm 0.82 & 1.38 \pm 0.35\end{array}$

' chemical analysis according to $\mathrm{AOAC}, 1990$

were fed the same amount of concentrate daily $(300 \mathrm{~g} / 10 \mathrm{~kg}$ liveweight). Grass hay was available ad libitum during the trial. All animals were slaughtered at a mean body weight of about $30 \mathrm{~kg}$.

\section{Measurements}

During the trial liveweight and feed intake were measured weekly. Rumen dry matter degradability was measured in three animals per group. Triplicate samples ( $200 \mathrm{mg}$ ) of the two experimental concentrates were placed in $2 \times 3 \mathrm{~cm}$ nylon bags (average pore size $50 \mu \mathrm{m}$ ) and inscrted in the rumen through an ocsophageal cannula at 48, 8 and $6 \mathrm{~h}$ before slaughtering. After slaughtering, bags were recovered and washed under running tap water and dried at $60^{\circ} \mathrm{C}$ for $48 \mathrm{~h}$. Ruminal $\mathrm{pH}$ values were mcasured by placing the probe into the rumen before emptying. Rumen contents were squeezed through a double layer of cheesecloth and then frozen at $-20^{\circ} \mathrm{C}$ for volatile fatty acid determination (AOAC, 1990). Metaphosforic acid was used to preserve samples. Carcass weight was measured at slaughtering. The value of $\mathrm{pH}$ in 
longissimus thoracis lumborum (LTL), semitendinosus (St) and semimembranosus (Sm) muscles was measured $24 \mathrm{~h}$ after slaughtering by using a portable $\mathrm{pH}$-meter (Hanna Instruments, HI 8424, Ingold pH-electrode T 406). Samples of LTL (between the $6^{\text {th }}$ and the $7^{\text {th }}$ rib) were taken from all carcasses and quickly frozen along with the right hind legs, then transferred to laboratory and stored at $-20^{\circ} \mathrm{C}$ until analyses were performed. Chemical composition was determined in LTL samples (AOAC, 1990); to evaluate fatty acid composition, ncutral lipids were extracted from meat samples (Bligh and Dyer, 1959), then methyl esters were obtained from neutral lipids (Sukhija and Palmquist, 1988) which were subjected to gas-chromatographic analysis for fatty acids using a Perkin Elmer (model 8700) gas chromatograph with a flame ionization detector and a fused silica capillary column, film thickness $0.25 \mu \mathrm{m}$ (Supelco, $30 \mathrm{~m} \times 0.25 \mathrm{~mm}$ i. d.). Helium was used as the carricr gas and column temperature was held at $160^{\circ} \mathrm{C}$ for $2 \mathrm{~min}$, and then increased at a rate of $3^{\circ} \mathrm{C} / \mathrm{min}$ from $160^{\circ} \mathrm{C}$ to a final temperature of $240^{\circ} \mathrm{C}$, held for $9 \mathrm{~min}$ ( $36.6 \mathrm{~min}$ total time of the gas chromatographic analysis).

Seventeen samples ( 9 control and 8 PFR) of Sm muscles were randomly taken and tested for sensory analysis (panel test) and shear force. Four carcasses from the control group were light carcasses and five heavy (under or over $13 \mathrm{~kg}$, respectively); three PFR carcasses were light and five heavy. The frozen legs were thawed for $48 \mathrm{~h}$ at $4^{\circ} \mathrm{C}$ at our laboratory and cooked in an electric oven at a temperature of $160^{\circ} \mathrm{C}$ until $75^{\circ} \mathrm{C}$ were reached in the inner part. $\Lambda$ thermocouples probe was put in the center of the Sm muscle to monitor the temperature. Immediately after cooking, samples of Sm muscle were taken for sensory analysis and shear force measurement. For the sensory characteristics, cubes $(1.27 \times 1.27 \times 1.9 \mathrm{~cm})$ were cut and served on pre-heated trays to maintain the samples at about $50^{\circ} \mathrm{C}$ (Cross et al., 1978). At each session, six trained panelists evaluated 2 or 3 samples on the basis of a $9-\mathrm{cm}$ line scale by placing a mark on the line to indicate their score for the following attributes: juiciness, tenderness and lamb flavour. Scores were recorded in $\mathrm{cm}$ and had a possible range from 0 (very dry, very tough, low intensity, respectively) to 9 (very juicy, very tender, high intensity, respectively). Shear force was determined in cylindrical samples (diameter of $12.5 \mathrm{~mm}$ ) of Sm muscle by using an Instron 1011 with a Warner-Bratzler device according to Trevisani (1993). Results of the panel test and shear force measurement were evaluated considering the two different diets and the weight of carcasses; those of the panel test were evaluated also considering the day when the session took place (direct comparison between control and PFR carcasses within the same weight class).

All data were subjected to ANOVA using the GLM procedure of SAS (SAS, 1996) and results were expressed as least squares means. 


\section{RESULTS $\Lambda$ ND DISCUSSION}

Rumen dry matter degradability of C and PFR concentrates at $6 \mathrm{~h}(76.1 \pm 9.3 \mathrm{vs}$ $69.8 \pm 8.5), 8 \mathrm{~h}(81.1 \pm 4.4$ vs $76.2 \pm 14.0)$, and $48 \mathrm{~h}(92.0 \pm 4.5$ vs $97.0 \pm 1.4)$ of incubation was not statistically different. Both samples of concentrates showed a degradability pattern similar to the one observed for starch (Michalet-Doreau and Sauvant, 1989). Volatile fatty acids and $\mathrm{pH}$ of rumen contents were also similar between samples (Table 2). Acetic, propionic, and butyric acid, as well as total volatile fatty acid production, were negatively correlated $(\mathrm{P}<0.001)$ to rumen $\mathrm{pH}$. The acetate : propionate ratio was not affected by the relatively high proportion of concentrate in the diet (64-66\% of total dry matter intake). Overall feed intake throughout the trial was $86.3 \pm 17.3$ and $81.5 \pm 17.2 \mathrm{~g} \mathrm{DM} / \mathrm{kg}$ metabolic weight (MW) for $\mathrm{C}$ and PFR groups, respectively. Hay intake increased from week 1 (12 $\mathrm{g} \mathrm{DM} / \mathrm{kg} \mathrm{MW}$ for both groups) to week 7 (40 g and $44 \mathrm{~g} \mathrm{DM} / \mathrm{kg} \mathrm{MW}$ for PFR and $\mathrm{C}$ groups, respectively) and then remained consistent until the end of the trial. Concentrate intake progressively increased throughout the trial (for PFR and C groups, respectively: 47 and $53 \mathrm{~g} \mathrm{DM} / \mathrm{kg} \mathrm{MW}$ at week 1 and 75 and $71 \mathrm{~g} \mathrm{DM} / \mathrm{kg}$ MW at week 10). This could be partially explained by the high substitution rate of concentrate ( $\varnothing$ rskov, 1986) and the local climate conditions (high values of temperature and relative humidity).

TABLE 2

Volatile fatty acids $(\mathrm{mM} / \mathrm{ml})$ and $\mathrm{pH}$ value of rumen contents, mean \pm s.e.

\begin{tabular}{lcc}
\hline & \multicolumn{2}{c}{ Diet } \\
\cline { 2 - 3 } Fatty acid & control & PFR \\
\hline $\mathrm{C}_{2: 0}$ & $0.0584 \pm 0.0053$ & $0.0626 \pm 0.0051$ \\
$\mathrm{C}_{3: 0}$ & $0.0240 \pm 0.0016$ & $0.0255 \pm 0.0015$ \\
$\mathrm{C}_{4: 1}$ & $0.0136 \pm 0.0017$ & $0.0141 \pm 0.0016$ \\
$\mathrm{C}_{5: 0}$ & $0.0027 \pm 0.0003$ & $0.0033 \pm 0.0003$ \\
$\sum\left(\mathrm{C}_{2: 0}-\mathrm{C}_{\mathrm{i}: 0}\right)$ & $0.0988 \pm 0.0082$ & $0.1054 \pm 0.0079$ \\
$\mathrm{pH}$ & $6.22 \pm 0.10$ & $6.08 \pm 0.10$ \\
\hline
\end{tabular}

Body liveweight and average daily gain during the first five weeks of the trial were significantly higher for the PFR group (Table 3). However, during the second part of the experiment, no significant differences were found between the two groups. The feed conversion ratio was not affected by diet: it decreased from 2.7 (first 3 weeks) to 4.5-5.5 during the last part of the experiment for both groups. These results confirm previous findings by Muscio el al. (1994) with Wurttemberg $x$ Ile de France x Gentile di Puglia crosses and by Lanza et al. (1983) with Barbaresca $x$ Comisana crosses slaughtered at 100 and 130 days of age, respectively. Overall performance observed in this trial demonstrates the superiority of crosses 
TABLE 3

Weekly body weight $(\mathrm{kg})$ and average daily gain $(\mathrm{g})$ of lambs, mean \pm s.e.

\begin{tabular}{lccc}
\hline & \multicolumn{2}{c}{ Diet } & \\
\cline { 2 - 3 } & control & PFR & significance \\
\hline Weekly body weight, week & & & \\
1 & $15.14 \pm 0.26$ & $16.51=0.25$ & $* * *$ \\
2 & $17.09 \pm 0.28$ & $17.50=0.27$ & n.s. \\
3 & $18.44 \pm 0.37$ & $19.22 \pm 0.36$ & n.s. \\
4 & $19.96 \pm 0.40$ & $21.68 \pm 0.39$ & ** \\
5 & $20.84 \pm 0.53$ & $21.56 \pm 0.51$ & n.s. \\
6 & $22.34 \pm 0.57$ & $23.44=0.56$ & n.s. \\
7 & $24.44 \pm 0.68$ & $24.67=0.64$ & n.s. \\
8 & $27.08=0.78$ & $27.57 \pm 0.73$ & n.s. \\
9 & $28.57 \pm 0.77$ & $28.97 \pm 0.72$ & n.s. \\
10 & $30.00 \pm 0.82$ & $29.99 \pm 0.77$ & n.s. \\
Average daily gain: & & & \\
week 1-5 & 144.30 .11 .4 & 193.60111 .0 & ** \\
week 5-10 & $254.16 \pm 14.7$ & $233.26 \pm 13.8$ & n.s. \\
\hline
\end{tabular}

significance: ***: $\mathrm{P}<0.001 ; * *$ : $\mathrm{P}<0.01$; n.s.: not significant

when compared with pure Comisana and Leccese lambs, which are considered milk typc brecds (Vicenti et al., 1989). Nevertheless, the data indicate that caution should be used in fattening this type of cross beyond 95-100 days of age because of the high fecd conversion ratio and the low average daily gain.

Slaughter data showed no significant differences between groups. Final body weight was $30.0 \pm 0.8$ and $29.9 \pm 0.8 \mathrm{~kg}$ and carcass weight was $13.3 \pm 0.4$ and $13.2 \pm 0.4$ $\mathrm{kg}$ for the $\mathrm{C}$ and $\mathrm{PFR}$ groups, respectively. The $\mathrm{pH}$ values were in the range of normal values and comparable between C and PFR treatment in LTL (5.57 10.04 vs $5.61 \pm 0.04)$, St $(5.65 \pm 0.05$ vs $5.65 \pm 0.04)$ and $\mathrm{Sm}(5.51 \pm 0.02$ vs $5.50 \pm 0.02)$ muscles. Our results were similar to those obtained in other experiments conducted in the past (Chrystall and Hagyard, 1976; Petersen and Blackmore, 1982; Severini et al., 1990). Chemical and fatty acid compositions of the LTL muscle are shown in Table 4. Chemical composition was similar to that obtained with lambs slaughtered at the same age and fed agro-industrial by-products (Marsico et al., 1994; Severini et al., 1994). As for fatty acid composition, data did not show significant differences between $\mathrm{C}$ and PFR lambs and were comparable to those obtained by Solomon et al. (1990). Thus, the quality of meat and fat was on a good standard level.

Results of sensory analysis and shear force measurements according with the two different dicts are given in Table 5. No significant differences in sensory characteristics and shear force were detected between the control and PFR groups. Little differences in sensory traits were observed only when light and heavy car- 
TABLE 4 Chemical composition (\%) and fatty acids composition ( $\mathrm{g} / 100 \mathrm{~g}$ total fatty acids) of intramuscular fat of muscle longissimus thorcis lumborum, meanxs.c.

\begin{tabular}{lrr}
\hline & \multicolumn{2}{c}{ Dict } \\
\cline { 2 - 3 } & \multicolumn{1}{c}{ control } & \multicolumn{1}{c}{ PFR } \\
\hline Dry matter & $23.74 \pm 0.21$ & $24.25 \pm 0.11$ \\
Crude protein & $19.20 \pm 0.19$ & $20.18 \pm 0.17$ \\
Crude fat & $2.51 \pm 0.16$ & $2.73 \pm 0.14$ \\
Ash & $1.12 \pm 0.01$ & $1.12 \pm 0.01$ \\
& & \\
$C_{14: 0}$ & $3.05 \pm 0.32$ & $3.61 \pm 0.30$ \\
$C_{16: 0}$ & $24.37 \pm 0.66$ & $25.29 \pm 0.62$ \\
$C_{16: 1}$ & $1.45 \div 0.10$ & $1.43 \pm 0.09$ \\
$C_{18: 0}$ & $22.26 \pm 2.26$ & $21.60 \pm 2.15$ \\
$C_{18: 1}$ & $37.10 \pm 0.90$ & $35.74 \pm 0.85$ \\
$C_{18: 2}$ & $10.78 \pm 1.47$ & $11.22 \pm 1.40$ \\
$C_{18: 3}$ & $0.99 \pm 0.10$ & $1.10 \pm 0.09$ \\
SFA & $49.70 \pm 1.83$ & $50.50 \pm 1.74$ \\
UFA $_{\text {MUFA }}$ & $50.32 \pm 1.83$ & $49.50 \pm 1.74$ \\
PUFA & $38.55 \pm 0.98$ & $37.18 \pm 0.93$ \\
\hline
\end{tabular}

TABLIF 5

Sensory traits and shear force value of Sm muscle, mean \pm s.e.

\begin{tabular}{|c|c|c|c|}
\hline & \multicolumn{2}{|c|}{ Dict } & \multirow[b]{2}{*}{ significance } \\
\hline & control & I'FR & \\
\hline All carcasses $(n o=17)$ & $\mathrm{n}=9$ & $\mathrm{n}=8$ & \\
\hline juiciness & $4.98+0.19$ & $4.83 \pm 0.18$ & n.s. \\
\hline tenderness & $5.45 \pm 0.20$ & $5.03: 0.19$ & $\mathrm{n} . \mathrm{s}$ \\
\hline flavour & $3.74 \pm 0.17$ & $3.70 \doteqdot 0.17$ & n.s. \\
\hline shear force $(\mathrm{N})$ & $48.96 \pm 4.10$ & $40.63 \pm 3.71$ & n.s. \\
\hline Light carcasses (no - -7) & $\mathrm{n}=4$ & $\mathbf{n}=3$ & \\
\hline juiciness & $5.58 \pm 0.30$ & $4.17+0.30$ & $* *$ \\
\hline tenderness & $6.17 \pm 0.31$ & $4.25+0.30$ & $* * *$ \\
\hline flavour & $3.85 \pm 0.22$ & $3.62 \pm 0.22$ & n.s. \\
\hline shear force $(\mathrm{N})$ & $42.97 \pm 4.35$ & $39.38 \pm 1.90$ & n.s. \\
\hline Heavy carcasses $(n o=10)$ & $n=5$ & $\mathrm{n}=5$ & \\
\hline juiciness & $4.77 \pm 0.27$ & $5.03 \pm 0.23$ & n.s. \\
\hline tenderness & $4.97 \pm 0.27$ & $5.43 \pm 0.23$ & n.s. \\
\hline flavour & $3.80 \pm 0.29$ & $3.79 \pm 0.25$ & n.s. \\
\hline shear force $(\mathrm{N})$ & $54.95 \pm 6.04$ & $41.39 \pm 6.13$ & n.s. \\
\hline
\end{tabular}

significance: ${ }^{* *}: \mathrm{P}<0.01 ; * * *: \mathrm{P}<0.001 ; \mathrm{n} . \mathrm{s} .:$ not significant 
casses were separately considered. However, as the number of carcasses in each group was small, these results only indicate trends upon which further experiments can be based. Mean values of juiciness and tenderness of Sm muscles of light carcasses $(<13 \mathrm{~kg}$ ) were higher in the control group than in the PFR group (Table 5). Direct comparison was possible only in two panel sessions. In one session control carcasses showed higher values of juiciness, tenderness and flavour, but only tenderness was higher in the other session. On the other hand, no significant differences were detected in the value of shear force between all light carcasses of the two groups. No significant differences in sensory charactcristics and shear force werc detected between $\mathrm{Sm}$ muscles of heavy carcasses $(>13 \mathrm{~kg}$ ) of the two groups (Table 5). However, dircet comparison in the panel test showed that values of juiciness, tenderness and flavour in the heavy carcasses of the PFR group were slightly higher than in control carcasses, in three of four sessions.

\section{CONCLUSIONS}

Our data point to the possibility of including pasta factory residues in a diet for fattening lambs. No significant effects on animal performance, carcass quality or meat composition were found. The results of panel tests showed that the Sm muscle from PFR light carcasses had a slightly lower quality than control carcasses, but such a difference was not detected in heavy carcasses and the panelists expressed even a moderate preference for PFR carcasses. No significant differences in sensory traits or shear force value between the control and PFR groups wcre detected when comparing all carcasses in each group. Furthermore, no differences in shear force value were observed when cvaluating light and heavy carcasses separately.

Therefore, on the basis of our overall results and considering the availability and the low price of this by-product, pasta factory residues could be an interesting choice for farmers to reduce feeding costs in small ruminant breeding.

\section{REFERENCES}

AOAC, 1990. Official Methods of Analysis. 15th Edition. Association of Official Analytical Chemists, Washington, DC

Bligh E. G., Dyer W. J., 1959. A rapid method of total lipid extraction and purification. Can. J. Biochem. Physiol. 37, 911-917

Centoducati P., Vicenti A., Braghieri A., Zezza L., 1994. Charactcristics of carcass and meat from lambs fed "torbido di Whirlpool" silage and wheat straw (in Italian). Sc. Tecn. Agr. 34, 19-25

Chrystall B. B., Hagyard C. J., 1976. Electrical stimulation and lamb tenderness. N7.J. Agric. Res. $19,7-11$ 
Cross H.R., Moen R., Stanficld S., 1978. Training and testing of judges for sensory analysis of meat quality. Food Technol. 32, 48-54

Lanza A., Mal' An M., Lanza E., 1983. Performance of Barbaresca x Comisana crossbred slaughtered at 130 days of age (in Italian). Zoot. Nutr. Anim. 9, 49-59

Marsico G., Viccnti A., Laudadio V., Vonghia G., Ciruzzi B., 1994. The effect of breeding system and agro-industrial by-product based diet on carcass composition of lambs slaughtered at 100 days of age (in Italian). Proceedings of the XI National Congress S.I.P.A.O.C., Perugia (Italy), pp. $137-140$

Michalet-Doreau B., Sauvant D., 1989. Influence de la nature du concentré, céréales ou pulpe de betterave, sur la digestion chez les ruminants. INRA Prod. Anim. 2 (4), 235-244

Muscio A., Sevi A., Melodia L., 1994. The effect of slaughter age and energy content in the diet on the performance of meat lambs (in Italian). Agric. Ricerca 3, 97-104

Ørskov E. R., 1986. Starch digestion and utilization in ruminants. J. Anim. Sci. 63, 1624-1633

Petersen G. V., Blackmore D. K., 1982. The effect of different slaughter methods on the post-mortem glycolysis of muscle in lambs. NZ Vet. J. 30, 195-198

Ragni M., Vicenti A., Lestingi A., Caputi Jambrenghi A., Vonghia (i., 1997. The use of grape skin for fattening lambs. Influence on productive and quanti-qualitative characteristics of the meat. Proceedings of XII National Congress of Scientific Association of Animal Production, Pisa (Italy), pp. 233-234

Scverini M., Vizzani A., Cenci G., Loschi A.R., Fantozzi P., 1990. The effect of topinambur (Helianthus tuberosus) residue silage feeding on lambs meat characteristic (in Italian). Ind. Alim. 29, 443-445

Severini M., Trevisani M., Loschi A.R., Ferzoco V., 1994. Qualitative characteristics of meat from lambs bred in Umbria Region (in Italian). Proceedings of XI National Congress of S.I.P.A.O.C., Perugia (Italy), pp. 133-136

Solomon M.B., Lynck G.P., Ono K., Parocray E., 1990. Lipid composition of muscle and adipose tissue from crossbred ram, wether and cryptorchid lambs. J. Anim. Sci. 68, 137-142

Statistical Analysis System Institute, 1996. SAS Uscr's Guidc. SAS Institute, Cary, North Caroline Sukhija P. S., Palmquist D. L., 1988. Rapid method for determination of total fatty acid content and composition of feedstuffs and faeces. J. Agric. Fond Chem. 36, 1202-1206

Trevisani M., 1993. Fvaluation of the instrumental testing of lamb meat tenderness (in Italian). Proceedings of Italian Socicty of Vetcrinary Sciences, Riccione (Italy), 47, 627-631

Viccnti A., Gallo R., Dario C., Bufano G., 1989. Reproductive and productive characteristics of the Comisana, Leccese and $\Lambda$ tamurana breeds in the Bari province (in Italian). Proceedings of the XXIV International Symposium of Animal Hushandry, Milano (Italy), pp. 243-247

Vicenti A., Marsico (i., Pinto F., Laudadio V., Vonghia G., Ciruzzi B., 1993. Use of almond hulls and saftlower cake in fattening lambs. Performance under farm condition. Proceedings of X National Congress of Scientific Association of Animal Production, Bologna (Italy), pp. 405-410

\section{STRESZCZENIE}

Zastosowanie rolno-przemyslowych produktów ubocznych w tuczu jagniąt: odpady przy produkcji makaronu. Wpływ na produkcję i jakość mięsa

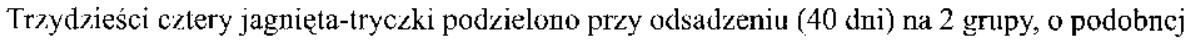
masic ciała $(13,5 \pm 0,25 \mathrm{~kg})$. W ciagu doświadczenia, przez $70 \mathrm{dni}$, wszystkie zwierzęta otrzymywa- 
ły jedną z dwóch różnych rodzajów paszy treściwej. Kontrolna pasza treściwa zawierała jęczmień jako główne źródło skrobi. Pasza doświadczalna była przygotowana 7 odpadów przemysłowych przy produkcji makronu (PFR), którymi częściowo zastąpiono jęczmien. W pierwszych pięciu tygodniach doświadczenia masa ciała $i$ średnie dzienne przyrosty były istotnie wiçksze $(\mathbf{P}<0,01) u$ jagniąt $z$ grupy PFR niż kontrolnych; w dalszej częśsi doświadczenia nie stwierdzono istotnych różnic między grupami. Rodzaj dawki nic miał wpływu na wykorzystanie pas\%y. Nie stwierdzono także różnic między grupami w wynikach ubojowych (30 kg waga końcowa). Skład chemičnny i skład kwasów tłuszczowych mięśnia longissimus thoracis lumborum, a także właściwości scnsorycznne oznaczone w mięśniu semimembranosus oraz siła łamania kości nie różniły się między porównywanymi grupami.

Na podstawie otrzymanych wyników można sądzić, że PFR może być wartościowym składnikiem dawki dla małych przeżuwaczy. 